\title{
In-vitro Anti-diabetic and Antioxidant Efficacy of Methanolic Extract of Encephalartos ferox leaves
}

\author{
Michael Chukwuka Ojo ${ }^{*}$, Foluso Oluwagbemiga Osunsanmi ${ }^{2}$, Godfrey Elijah Zaharare ${ }^{2}$, Rebamang Anthony \\ Mosa', Nkosinathi David Cele', Michael Osawemi Oboh², Andy Rowland Opoku
}

\section{Michael Chukwuka Ojo ${ }^{1 *}$, Foluso Oluwagbemiga Osunsanmi², Godfrey Elijah Zaharare ${ }^{2}$, Re- bamang Anthony Mosa', Nkosinathi David Cele', Michael Osawemi Oboh², Andy Rowland Opoku ${ }^{1}$}

'Department of Biochemistry and Microbiology, University of Zululand, Republic of SOUTH AFRICA. ${ }^{2}$ Department of Agricultural Science, University of Zululand, Republic of SOUTH AFRICA.

Correspondence

Mr. Michael Chukwuka Ojo

Department of Biochemistry and Microbiology, University of Zululand, Private Bag X1001, KwaDlangezwa- 3886 SOUTH AFRICA.

Phone no : +27631695249 $+27840105100$

E-mail: mikekonyegwachie2015@gmail. com

History

- Submission Date: 12-09-2018

- Review completed: 12-11-2018;

- Accepted Date: 12-12-2018

DOI : 10.5530/pj.2019.11.71

Article Available online http://www.phcogj.com/v11/i3

\section{Copyright}

(C) 2019 Pharmacognosy Journal. This is an open-access article distributed under the terms of the Creative Commons Attribution 4.0 International license.

\begin{abstract}
Background: Diabetes mellitus has been identified as one of the global cause of disability and death. Objectives: The study aim to investigate the in-vitro antidibetic and antioxidant activities of methanolic extract of Encephalartos ferox leaves. Materials and Methods: The plant was screened for its Phytochemical composition. The plant material was extracted with methanol and the methanolic extract was screened (in-vitro) for its antioxidant activity using ABTS and DPPH assays. The potential antidiabetic activity of the plant extract was evaluated against some carbohydrates ( $\alpha$ - amylase and $\alpha$-glucosidase) and lipid (pancreatic lipase) digestive enzymes. The inverted intestinal sac model was also used to investigate the effect of the extract on intestinal glucose absorption. The anti-protein glycation activity of the extract was determined using haemoglobin. Results: The phytochemical screening revealed the presence of most of the phytochemicals (Tannins, Flavonoids, Terpenoids, Alkaloids etc) that were screened for. The crude extract exhibited the antidiabetic potential as it significantly $(P<$ 0.05 ) inhibited $\alpha$-glucosidase and pancreatic lipase in a dose dependent fashion. The extract also effectively reduced intestinal glucose absorption. The extract further showed antioxidant activity by efficiently scavenging ABTS and DPPH radicals with $I_{50}$ values of $68.3 \mu \mathrm{g} / \mathrm{ml}$ and $308 \mu \mathrm{g} / \mathrm{ml}$, respectively. The extract also inhibited haemoglobin glycation, thus displaying the anti-protein glycation potential. Conclusion: It is apparent that E. ferox extract could serve as scaffold for diabetic therapy. For future study, cytotoxicity profile and in vivo investigation of the antidiabetic activity of the crude extract are essential.
\end{abstract}

Key words: Diabetic, Hypoglycaemic, Protein- glycation, Flavonoids, Hyperglycaemia, Hyperlipidemia.

\section{INTRODUCTION}

Diabetes Mellitus (DM) is a progressive metabolic disorder of carbohydrates and lipids that is characterized by hyperglycemia. ${ }^{1} \mathrm{DM}$ is known to result from defect in insulin secretion, action or both. ${ }^{2}$ Poor management of diabetes mellitus can degenerate into debilitating conditions including heart attack, stroke, kidney failure, leg amputation, vision loss, nerve damage and erectile dysfunction. ${ }^{1}$ The inability of the cells to assimilate glucose formed via stepwise catabolism of carbohydrates with $\alpha$-amylase and $\alpha$-glucosidase, leads to hyperglycemia. Likewise, hyperactivity of pancreatic lipase results to increase in lipid metabolism which also triggers hyperlipidemia. ${ }^{3-4}$ Therefore, hyperglycemia and hyperlipidemia continue to be the underlying factors in the on-set of diabetes mellitus and its complications. ${ }^{5}$ In addition, reactive oxygen species also play crucial role in the pathogenesis of diabetes mellitus. ${ }^{6}$

Despite the potency of currently used diabetic drugs such as acarbose, Voglibose, Miglitol, insulin mimetics and secretagogues, they still are associated with adverse side effects. ${ }^{7}$ Therefore, the search for alternative remedy from plant origin has become paramount. Medicinal plants are known to possess less or no aftermath effect, inexpensive and easily available especially to rural dwellers. ${ }^{8}$

Encephalartos ferox (G. Bertol) Lehm is a small cycad which belongs to the family Zamiaceae and endemic in northern Kwazulu Natal. E. ferox contains pinnately compound leaves that can grow up to two metres in length and a trunk that is a metre long which lies under the surface of the earth. E. ferox grows easily on a well-drained soil, moderate temperatures and abundant of water. E. ferox propagates using cones that are sexually dimorphic. It is commonly called Tongaland broodboom in Afrikaans, Umthobane and Uthobani in Zulu and Chihanga in Tonga. ${ }^{9-10}$ In the past, E. ferox stems were used as meal while the leaves were used for the treatment of estrogen-dependent tumor. ${ }^{11}$ Contemporarily, Encephalartos ferox leaves are also used by traditional healers in Kwazulu Natal province of South Africa to manage diabetes and its complications, especially diabetic wounds. However,
Cite this article: Ojo MC, Osunsanmi FO, Zaharare GE, Mosa RA, Cele ND, Oboh MO, et al. Invitro Anti-diabetic and Antioxidant Efficacy of Methanolic Extract of Encephalartos ferox leaves. Pharmacog J. 2019;11(3):455-60. 
the medicinal folklores usage still lacks scientific validation. This is the first report on the in-vitro anti-diabetic and anti-oxidant potentials of methanolic extract of $E$. ferox leaves to the best of our knowledge.

\section{MATERIALS AND METHODS}

\section{Chemicals}

All the chemicals and kits used in this study were of analytical grades and were purchased from Sigma Aldrich Co.Ltd (Steinheim, Germany)

\section{Plant identification}

The leaves of Encephalartos ferox were collected in May, 2017 from Mbazwana $\left(27.4937^{\circ} \mathrm{S}, 32.5882^{\circ} \mathrm{E}\right) \mathrm{KwaZulu}-\mathrm{Natal}$, South Africa. The plant's sample was taken to Department of Botany, University of Zululand and was authenticated by Dr. N.T Ntuli. The plant's sample with specimen number VH04 has been deposited at the University herbarium.

\section{Plant extraction}

The leaves of Encephalartos ferox were air dried and pulverized into fine powder. Pulverized sample (50 g) was extracted with methanol $(1: 5 \mathrm{w} / \mathrm{v})$ using mechanical shaker $\left(150 \mathrm{rpm} ; 25^{\circ} \mathrm{C}\right)$ for $72 \mathrm{~h}$. The extract was filtered using Whatman filter paper 1 and concentrated using a Heidolph rotor evaporator $\left(45 \mathrm{rpm}, 40^{\circ} \mathrm{C}\right)$ to yield $8.4 \%$ of crude extract.

\section{Phytochemicals screening}

The phytochemicals screening was conducted on the pulverized samples following the method described by Odebiyi and Sofowara and Harbone. ${ }^{12-13}$ The following phytochemicals were screened for; saponins, tannins, flavonoids, alkaloids and terpenoids.

\section{Haemoglobin glycation}

The haemoglobin glycation inhibitory activity of the extracts was determined using the method of Pal and Dutta. ${ }^{14}$ The reaction mixture consisted of $500 \mu \mathrm{l}$ of various concentrations $(0-2 \mathrm{mg} / \mathrm{ml})$ of the extract, haemoglobin $(0.06 \%)$, ciprofloxacin $(0.02 \%)$ and fructose $(2 \%)$. All the components of the reaction mixture were prepared in $0.01 \mathrm{M}$ phosphate buffer ( $\mathrm{pH} 7.4)$. The mixture was incubated $\left(37^{\circ} \mathrm{C}\right)$ in the dark for $72 \mathrm{~h}$. Gallic acid was used as positive control. Absorbance was read at $443 \mathrm{~nm}$ using spectrophotometer.

\section{a-Glucosidase inhibitory activity}

a-Glucosidase inhibitory activity of the extracts was investigated following the method described by Rayar and Manivannan. ${ }^{15}$ A reaction mixture consisting of $50 \mu \mathrm{l}$ of phosphate buffer ( $10 \mathrm{mM}, \mathrm{pH} 6.8), 10 \mu \mathrm{l}$ of $\alpha$-glucosidase $(0.5 \mathrm{unit} / \mathrm{ml})$ and $20 \mu \mathrm{l}$ of the plant extract at various concentrations $(0-2 \mathrm{mg} / \mathrm{ml})$ were pre-incubated at $37^{\circ} \mathrm{C}$ for $15 \mathrm{~min}$. Thereafter, $20 \mu \mathrm{l}$ of 4 -nitrophenyl- $\beta$-D glucoparanoside $(2.5 \mathrm{mM})$ were added to initiate the reaction. The mixture was then incubated at $37^{\circ} \mathrm{C}$ for another $20 \mathrm{~min}$. The reaction was terminated by adding $50 \mu \mathrm{l}$ of sodium carbonate $(0.1 \mathrm{M})$. Absorbance was read at $405 \mathrm{~nm}$ using spectrophotometer.

\section{Pancreatic lipase inhibitory activity}

Pancreatic lipase inhibitory activity of the extract was ascertained by the method of Slanc et al. ${ }^{16}$ The reaction mixture consisting of $125 \mu \mathrm{l}$ of Tris- $\mathrm{HCl}$ buffer $(75 \mathrm{mM}, \mathrm{pH}$ 8), $75 \mu \mathrm{l}$ of various concentration of the extract $(0-5 \mathrm{mg} / \mathrm{ml})$ and $50 \mu \mathrm{l}$ of lipase (sigma) $(10 \mathrm{mg} / \mathrm{ml})$ in a beaker $\left(50 \mathrm{ml}\right.$ ) was incubated at $37^{\circ} \mathrm{C}$ for $15 \mathrm{~min}$. Afterwards, $25 \mu \mathrm{l}$ of $3,3 \mathrm{mM}$ p-nitrophenyl palmitate (sigma) was added to initiate the reaction. The reaction mixture was then incubated for $30 \mathrm{~min}$. The blank was made of methanol and water (1:1) whereas or list at served as positive control. Absorbance was read at $405 \mathrm{~nm}$ using spectrophotometer.

\section{Animal experiment}

Ethical clearance certificate (UZREC 171110-030 PGD 2014/53) was collected from University of Zululand Ethics Committee for the use of animals for experiment. The procedures for animal experiments were adhered. ${ }^{17}$ Sprague-Dawley rats $(250 \mathrm{~g})$ were collected from animal house of Department of Biochemistry and Microbiology, University of Zululand. The animals were kept under standard environmental conditions $\left(25^{\circ} \mathrm{C} ; 12: 12\right.$ lights: dark cycle) with free access to safe drinking water and pellet feeds. The animals were acclimatized for 5 days.

\section{Intestinal glucose absorption}

Intestinal glucose absorption was determined following the method of Said et al. ${ }^{18}$ Two Sprague-Dawerly rats $(250 \mathrm{~g})$ were sacrificed by cervical dislocation and dissected to harvest the intestine. The small intestines were rinsed with distilled water $(50 \mathrm{ml})$ to remove blood stains. Thereafter, the intestines were inverted and the bottom part was tied up before being filled with the Kerbs-Henselleit buffer. The upper part of the intestine was also tied after it has been filled. The tied intestinal sacs were then placed in a beaker $(100 \mathrm{ml})$ containing $7 \mathrm{ml}$ of starch solution $(1 \%), 2 \mathrm{ml}$ pancreatin $(1 \%)$ and $2 \mathrm{ml}$ plant extract $(5 \mathrm{mg} / \mathrm{ml})$. Tween 20 served as the negative control. The beakers containing the reaction mixtures were then incubated at $37^{\circ} \mathrm{C}$ for $2 \mathrm{~h}$. Glucose oxidase assay kit (Sigma) was used to estimate the amount of glucose in the intestinal sac and beaker. The amount of glucose obtained in the beaker represented the amount of starch digested while the glucose inside the sac represented the amount of glucose absorbed by the intestine.

\section{1, -Diphenyl-2-Picryl Hydrazyl (DPPH) scavenging activity}

DPPH scavenging activity of the extract was determined by method of Brad. ${ }^{19}$ The DPPH $(0.02 \mathrm{mg} / \mathrm{ml})$ was mixed $(1: 1 \mathrm{v} / \mathrm{v})$ with various concentration of plant extract $(0-4 \mathrm{mg} / \mathrm{ml})$. Each mixture was made to stand for $60 \mathrm{~min}$ at $25^{\circ} \mathrm{C}$ and the absorbance was read at $517 \mathrm{~nm}$ using spectrophotometer. Ascorbic acid and Butylated Hydroxyl anisole (BHA) served as the positive controls.

\section{ABTS Scavenging activity}

Assessment of ABTS scavenging activity of the extract was carried out with the method of Re et al..$^{20}$ ABTS solution $(0.003 \mathrm{~g} / \mathrm{ml})$ was mixed in the ratio $1: 1(\mathrm{v} / \mathrm{v})$ with different concentrations of the plant extract. The mixture was left to stand for $14 \mathrm{~min}$ at $25^{\circ} \mathrm{C}$ and the absorbance was read at $734 \mathrm{~nm}$ using spectrophotometer. Ascorbic acid and BHA served as the positive controls.

\section{Data analysis}

All the data were triplicated and expressed as mean \pm standard-deviation. The data was analyzed using one-way Analysis of variance (ANOVA). The $\mathrm{IC}_{50}$ values were calculated using the graph pad prism. The percentage (\%) inhibitions of the extract against the measured parameters were calculated using the formula; \% Inhibition $\left.=\left(A_{0}-A_{1}\right) / A_{0}\right) \times 100$. Where, $A_{0}$ is the absorbance value of the control and $A_{1}$ is the absorbance of the extracts or essential oils.

\section{RESULTS}

\section{Phytochemical studies}

The phytochemical constituent of E. ferox is depicted in Table 1. The results revealed that the plant consist of tannins, flavonoids, terpenoids, alkaloids, but deficient in saponins and steroids. 
Table 1: Phytochemical constituents of $E$. ferox.

\begin{tabular}{cc}
\hline Phytochemicals & Encephalartos ferox \\
\hline Tannins & + \\
Saponins & - \\
Flavonoids & + \\
Terpenoids & + \\
Alkaloids & + \\
Steroids & - \\
\hline
\end{tabular}

Sign notations: + Present, - Absent

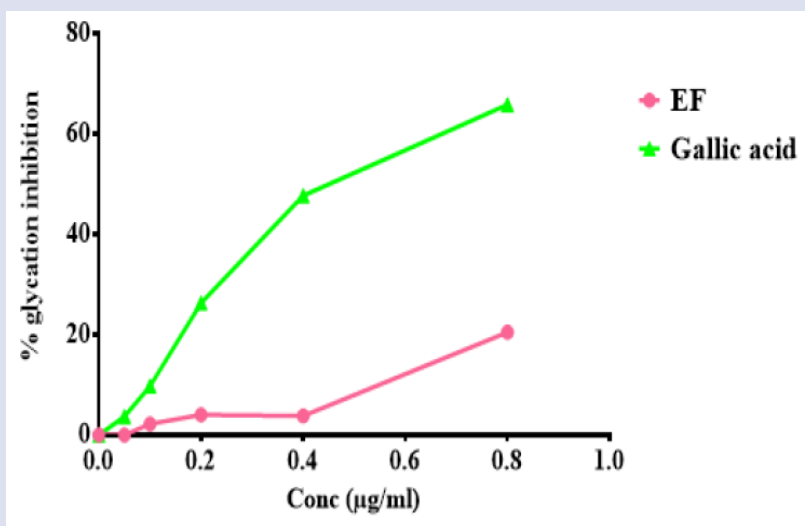

Figure 1: The result of the anti- haemoglobin glycation efficacy of E. ferox. $\mathrm{IC}_{50}$ value of Gallic acid $455 \mu \mathrm{g} / \mathrm{ml}$. Data expressed as mean \pm SD.

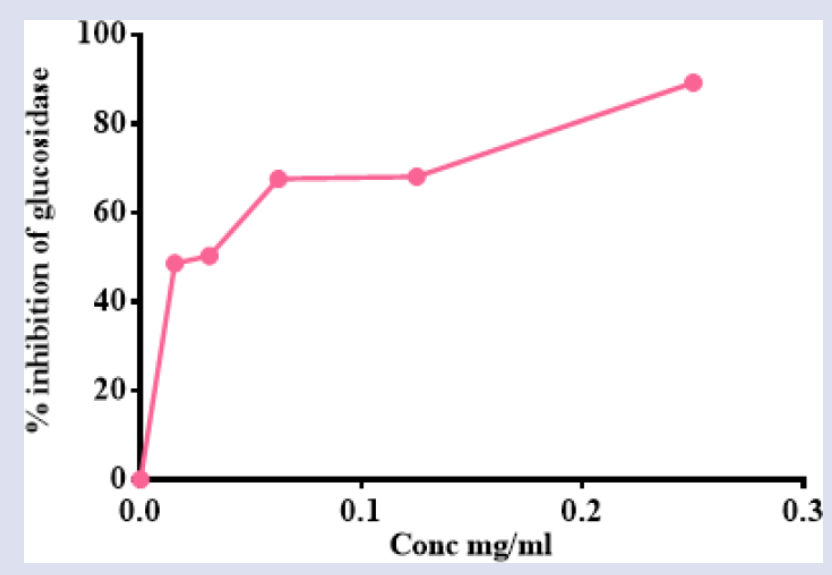

Figure 2: The result of the inhibitory effect of $E$. ferox on a-glucosidase. Data expressed as mean \pm SD.

\section{Haemoglobin- glycation}

The percentage haemoglobin- glycation inhibitory potential of E. ferox was represented by Figure 1. The E. ferox significantly $(P<0.05)$ inhibited haemoglobin- glycation with the optimal inhibitory activity observed at $0.4 \mathrm{mg} / \mathrm{ml}$. In addition to this, E. ferox $(0.4 \mathrm{mg} / \mathrm{ml})$ possessed similar anti-haemoglobin glycating activity to gallic acid, the positive control.

\section{a- glucosidase activity}

The results revealed that $E$. ferox inhibited a-glucosidase activity in a dose dependent manner as depicted by Figure 2 . The optimal inhibitory
Table 2: The results ( $\mathrm{IC}_{50}$ values) of $E$. ferox on a-glucosidase and pancreatic lipase inhibition

\begin{tabular}{ccc}
\hline Compound & a-glucosidase $(\mathrm{mg} / \mathrm{ml})$ & Pancreatic lipase $(\mathrm{mg} / \mathrm{ml})$ \\
\hline E. ferox & $2.9 \times 10^{-2}$, & $179 \times 10^{-2}$ \\
Orlistat & - & $3.92 \times 10^{-2}$ \\
\hline
\end{tabular}

Data are presented as mean $\pm S D, n=3$.

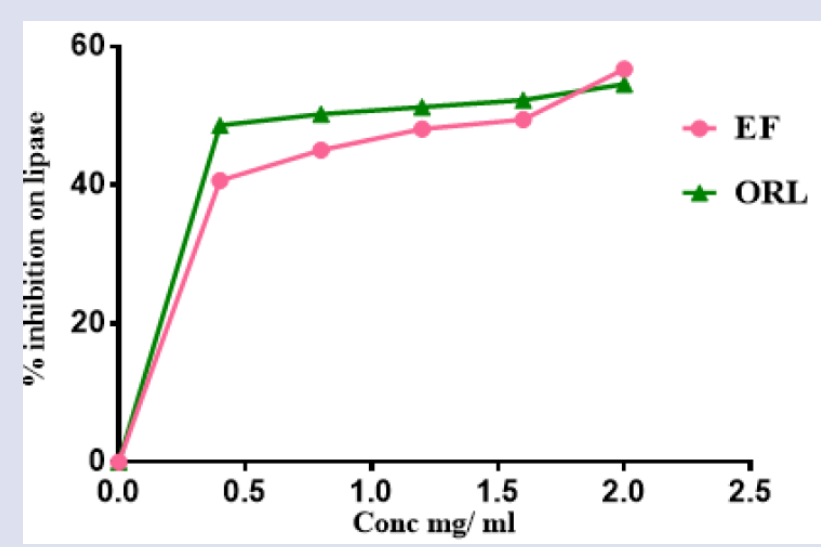

Figure 3: Shows the inhibitory activity of $E$. ferox against pancreatic lipase. Data expressed as mean \pm SD.

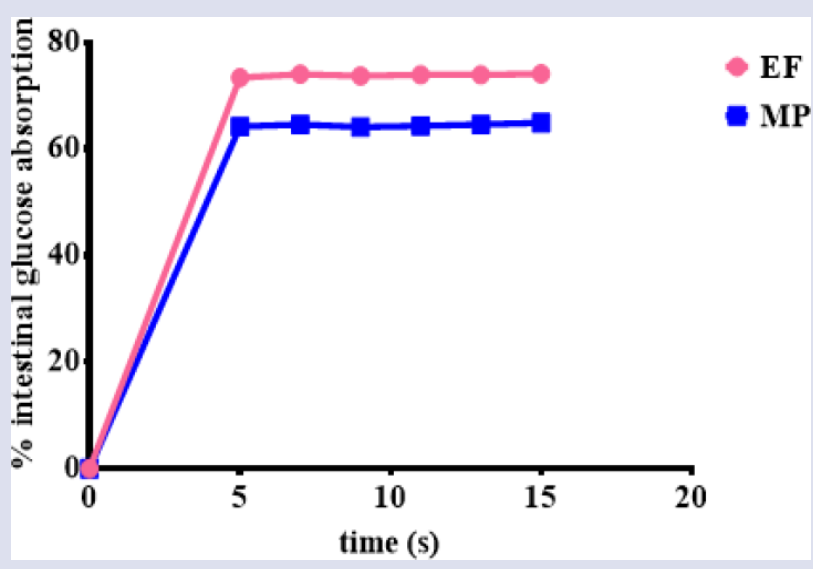

Figure 4: Shows the effect of $E$. ferox on intestinal glucose absorption. Data expressed as mean \pm SD.

activity was observed at the highest concentration $0.25 \mathrm{mg} / \mathrm{ml}$, whereas the minimum inhibitory activity was at $0.0312 \mathrm{mg} / \mathrm{ml}$. The $\mathrm{IC}_{50}$ values of E. ferox was $0.0293 \mathrm{mg} / \mathrm{ml}$ (Table 2).

\section{Pancreatic lipase activity}

The inhibitory efficacy of $E$. ferox against pancreatic lipase was presented in Figure 3. E. ferox displayed high inhibitory activity that is concentration dependent. Furthermore, it was observed that E. ferox showed twice the $\mathrm{IC}_{50}$ value of or list at, positive control $(1.79 \mathrm{mg} / \mathrm{ml}$ ) (Table 2). 


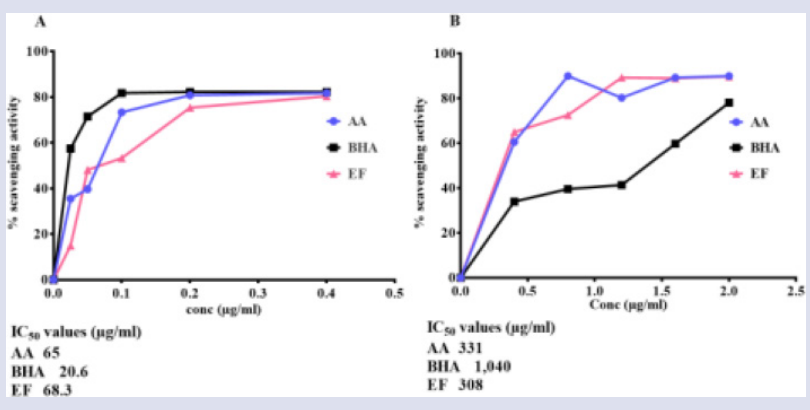

Figure 5: The results of the scavenging activity of $E$. ferox against ABTS (A) and DPPH (B) radicals with the $I_{50}$ values. Data expressed as mean \pm SD.

\section{Intestinal glucose absorption}

The result revealed that the crude extract of E. ferox significantly $(P<0.05)$ reduced glucose absorption in the intestine compared to control as presented in Figure 4. Addition to this, it was also observed that at 5 secs $E$. ferox decreased intestinal glucose absorption however further exposure time seem not to influence glucose absorption.

\section{ABTS and DPPH activity}

The results of the ABTS and DPPH scavenging activity of the crude extract of the plant are given in Figure 5. The extract showed antioxidant activity by efficiently scavenging ABTS and DPPH radicals in concentration dependent manner. The $\mathrm{IC}_{50}$ values of the extract were $68.3 \mu \mathrm{g} / \mathrm{ml}$ and $308 \mu \mathrm{g} / \mathrm{ml}$, against ABTS and DPPH, respectively.

\section{DISCUSSION}

Diabetes mellitus connotes starvation of cells amidst abundance of plasma glucose. ${ }^{21}$ Modulation of carbohydrate and lipid metabolizing enzymes by dietary supplement are desirable therapeutic approach to abating diabetes and its complications. ${ }^{3,22}$ Medicinal plant usage in ameliorating metabolic diseases is gaining more favor in research due to its phytochemical constituents. ${ }^{23}$ In this present study, E. ferox is known to possess tannins, flavonoids, terpenoids, alkaloids.

During diabetes condition, Advanced Glycated End-products (AGEs) become more pronounced. AGEs stimulate the production of pro-inflammatory cytokines which further aggravate diabetic complications ${ }^{24}$ Likewise, hemoglobin glycation has also been established to be significantly increased in diabetes. Interestingly, the extract displayed its anti-protein glycation potency by preventing hemoglobin glycation (Figure 1). The extract's anti-haemoglobin glycation activity could be linked to its antioxidant potential, since the glycosylation of proteins are oxidation process. ${ }^{25}$ This finding was in accordance with the report of Hosseini et al..$^{25}$ in which red clover and alfalfa extracts inhibited hemoglobin glycosylation.

Furthermore, prolonged post-prandial blood glucose spike is associated with diabetes mellitus. ${ }^{4}$ Alpha-glucosidase is pivotal in increasing plasma glucose after the consumption of carbohydrate rich meal therefore, inhibiting the action of $\boldsymbol{\alpha}$-glucosidase is therapeutic in managing diabetes complications. In this study, E. ferox attenuated $\alpha$-glucosidase activity (Figure 2). This activity could be linked to its alkaloids and terpenoids components (Table 1). In previous studies, alkaloids and terpenoids were reported to inhibit a-glucosidase activity and $\alpha$-amylase. ${ }^{26-27}$ Likewise, these findings synchronized with the report of Sompong et al. and Riyaphan et al. ${ }^{28-29}$ in which some plants extract inhibited carbohydrate and lipid metabolism enzymes activities.
High level of triglycerides and cholesterol have been implicated in the onset of type 2 diabetes. ${ }^{30}$ Attenuation of pancreatic lipase activity reduced free fatty acids availability for onward absorption into the small intestine, thus reversed hyperlipidemia. ${ }^{31}$ The study revealed that E. ferox inhibited pancreatic lipase activity (Figure 3). This implies that. E. ferox could effectively reduce post-prandial free fatty acid and subsequently ameliorate diabetes symptoms. The anti-hyperlipidemic activity of the extract, could be attributed to its phenolic constituents. Phenol compounds have been demonstrated to inhibit pancreatic lipase by competitively binding to the enzyme active site..$^{21}$ In addition, E. ferox effectively reduced intestinal glucose absorption into the blood (Figure 4). This indicates that E. ferox disrupts glucose absorption mechanism in the small intestine. Some plants extracts have also been reported to attenuate intestinal glucose absorption into the blood. ${ }^{32-34}$

Oxidative stress caused by the imbalance between free radicals and cellular oxidants scavengers in favour of free radicals has been implicated in the etiology of insulin resistance and diabetic complications. ${ }^{35}$ ABTS and DPPH assay were widely used to monitor the antioxidant potential of the extract. These methods accommodated for Single Electron Transfer (SET) and Hydrogen Atom Transfer (HAT) activities. ${ }^{36-37}$ In this study, the extract displayed good antioxidant activities by scavenging free radicals (Figure 5). These findings were in accordance to previous studies in which medicinal plants were regarded as effective antioxidant agents. ${ }^{36}$ The better antioxidant activity of the extract than AA and BHA in DPPH assay further affirms its potency (Figure 5). The extract antioxidant activity could be attributed to its phenolic constituent. Phenolic compounds have been established to confer on medicinal plants their antioxidant potential, based on the hydroxyl groups in their chemical structure. ${ }^{23}$

\section{CONCLUSION}

The antidiabetic efficacy of $E$. ferox can be attributed to the scavenging of antioxidants, attenuation of carbohydrate and lipid metabolizing enzymes, inhibition of glucose absorption and prevention of protein glycation. All these activities were based on the extract's phytochemical constituents. Therefore, the extract could be a promising therapeutic in management of diabetic complications. Addition to this, folklore usage of this plant as diabetes remedy was justified. For further study, cytotoxicity profile, in vivo antidiabetic activity and isolation of bioactive compounds are essential.

\section{ACKNOWLEDGEMENT}

The authors acknowledge Research office of University of Zululand for their financial supports

\section{CONFLICT OF INTEREST}

The authors declare no conflict of interest.

\section{ABBREVIATIONS}

AA: Ascorbic acid; ABTS: 2,21- Azino-bis (3-ethylbenzthiazoline-6sulfonic acid); BHA: Butylated hydroxy anisole; DM: Diabetes mellitus; DPPH: 2,2-diphenyl-1-picrylhydrazyl; E. ferox: Encephalartos ferox; HAT: Hydrogen electron transfer; IC $_{50}$ : Inhibition concentration; SET: Single electron transfer.

\section{REFERENCES}

1. Shobana S, Sreerama YN, Malleshi NG. Composition and enzyme inhibitory properties of finger millet (Eleusine coracana L.) seed coat phenolics: Mode of inhibition of $\alpha$-glucosidase and pancreatic amylase. Food Chem. 2009;115(4):1268-73.

2. Elberry AA, Harraz FM, Ghareib SA, Gabr SA, Nagy AA, Abdel-Sattar E. Methanolic extract of Marrubium vulgare ameliorates hyperglycemia and dyslipidemia 
in streptozotocin-induced diabetic rats. Int J of DM. 2015;3(1):37-44.

3. Hanhineva K, Törrönen R, Bondia-Pons I, Pekkinen J, Kolehmainen $M$, Mykkänen $\mathrm{H}$, et al. Impact of dietary polyphenols on carbohydrate metabolism. Int J Mol Sci. 2010;11(4):1365-402.

4. Rossi EJ, Sim L, Kuntz DA, Hahn D, Johnston BD, Ghavami A, et al. Inhibition of recombinant human maltase glucoamylase by salacinol and derivatives. The FEBS J. 2006;273(12):2673-83

5. Ogden CL, Carroll MD, Curtin LR, McDowell MA, Tabak CJ, Flegal KM. Prevalence of overweight and obesity in the United States, 1999-2004. JAMA 2006;295(13):1549-55

6. Bloch-Damti A, Bashan N. Proposed mechanisms for the induction of insulin resistance by oxidative stress. Antioxid Redox Signal. 2005;7(11-12):1553-67.

7. Hung HY, Qian K, Morris-Natschke SL, Hsu CS, Lee KH. Recent discovery of plant-derived anti-diabetic natural products. Nat Prod Rep. 2012;29(5):580-606.

8. Shokeen P, Anand P, Murali YK, Tandon V. Antidiabetic activity of $50 \%$ ethanolic extract of Ricinus communis and its purified fractions. Food Chem Toxicol. 2008;46(11):3458-66.

9. Vorster P. Classification concepts in Encephalartos (Zamiaceae). Cycads classification concepts and recommendations. Wallingford: CABI Publishing. 2004;69-83.

10. Cousins SR, Williams VL, Witkowski ET. Sifting through cycads: A guide to identifying the stem fragments of six South African medicinal Encephalartos species. RSA J Bot. 2013;84:115-23.

11. Kowalska MT, Itzhak Y, Puett D. Presence of aromatase inhibitors in cycads. $J$ Ethnopharmacol. 1995;47(3):113-6.

12. Odebiyi OO, Sofowora EA. Phytochemical screening of Nigerian medicina plants II. Lloydia. 1978;41(3):234-46.

13. Harbone JB. Phenolic compounds. Phytochemical Methods. 1973;271-80

14. Pal DK, Dutta S. Evaluation of the Antioxidant activity of the roots and Rhizomes of Cyperus rotundus L. Indian J Pharm Sci. 2006;68(2).

15. Rayar A, Manivannan R. In vitro alpha-amylase and alpha-glucosidase inhibition activity of umbelliferone and beta-ionone isolated from coriandrum sativum linn. World J Pharm Pharm Sci. 2016;5(1):1280-9

16. Slanc P, Doljak B, Kreft S, Lunder M, Janeš D, Štrukelj B. Screening of selected food and medicinal plant extracts for pancreatic lipase inhibition. Phytotherapy Research: An Int J Devo Pharm Toxicol Eval Nat Prod Deriv. 2009;23(6):874-7.

17. Office of Laboratory Animal Welfare. Public Health Service policy on humane care and use of laboratory animals. 2002.

18. Said O, Fulder S, Khalil K, Azaizeh H, Kassis E, Saad B. Maintaining a physiological blood glucose level with 'glucolevel', a combination of four anti-diabetes plants used in the traditional Arab herbal medicine. Evid Based Complement Alternat Med. 2008;5(4):421-8.

19. Brand-Williams W, Cuvelier ME, Berset CL. Use of a free radical method to evaluate antioxidant activity. LWT-Food Sci Technol. 1995;28(1):25-30.

20. Re R, Pellegrini N, Proteggente A, Pannala A, Yang M, Rice-Evans C. Antioxidant activity applying an improved ABTS radical cation decolorization assay. Free Radic Biol Med. 1999;26(9-10):1231-7.

21. Matschinsky FM, Magnuson MA, Zelent $D$, Jetton $T L$, Doliba N, Han $Y$, et al. The network of glucokinase-expressing cells in glucose homeostasis and the potential of glucokinase activators for diabetes therapy. Diabetes. 2006;55(1):1-2
22. Zhang B, Deng Z, Ramdath DD, Tang Y, Chen PX, Liu R, et al. Phenolic profiles of 20 Canadian lentil cultivars and their contribution to antioxidant activity and inhibitory effects on $\alpha$-glucosidase and pancreatic lipase. Food Chem. 2015;172:862-72

23. Coman $C$, Rugina OD, Socaciu C. Plants and natural compounds with antidiabetic action. Notulae Botanicae Horti Agrobotanici Cluj-Napoca. 2012;40(1):314-25.

24. Rice-Evans CA, Miller NJ, Paganga G. Structure-antioxidant activity relationships of flavonoids and phenolic acids. Free Radic Biol Med. 1996;20(7):933-56.

25. Hosseini M, Asgary S, Najafi S. Inhibitory potential of pure isoflavonoids, red clover and alfalfa extracts on hemoglobin glycosylation. Arya Atherosclerosis. 2015;11(2):133.

26. Önal S, Timur S, Okutucu B, Zihnioglu F. Inhibition of $\alpha$-glucosidase by aqueous extracts of some potent antidiabetic medicinal herbs. Prep Biochem Biotechnol. 2005;35(1):29-36

27. Suantawee T, Wesarachanon K, Anantsuphasak K, Daenphetploy T, Thien-Ngern $\mathrm{S}$, Thilavech T, et al. Protein glycation inhibitory activity and antioxidant capacity of clove extract. J Food Sci Technol. 2015;52(6):3843-50.

28. Sompong W, Muangngam N, Kongpatpharnich A, Manacharoenlarp C Amorworasin C, Suantawee T, et al. The inhibitory activity of herbal medicines on the keys enzymes and steps related to carbohydrate and lipid digestion. BMC Complement Altern Med. 2016;16(1):439.

29. Riyaphan J, Jhong CH, Tsai MJ, Lee DN, Leong MK, Weng CF. Potent Natural Inhibitors of Alpha-Glucosidase and Alpha-Amylase against Hyperglycemia in vitro and in vivo.

30. Jacobson TA, Miller M, Schaefer EJ. Hypertriglyceridemia and cardiovascular risk reduction. Clin Ther. 2007:29(5):763-77.

31. Marrelli M, Loizzo MR, Nicoletti M, Menichini F, Conforti F. Inhibition of key enzymes linked to obesity by preparations from Mediterranean dietary plants: effects on $\alpha$-amylase and pancreatic lipase activities. Plant Foods Hum Nut. 2013;68(4):340-6.

32. Li JM, Che CT, Lau CB, Leung PS, Cheng $\mathrm{CH}$. Inhibition of intestinal and renal $\mathrm{Na}^{+}$-glucose cotransporter by naringenin. The Int J Biochem Cell Biol. 2006;38(5-6):985-95.

33. Lee MS, Thuong PT. Stimulation of glucose uptake by triterpenoids from Weigela subsessilis. Phytotherapy Research: An Int J Devo to Pharm and Toxi Eval Nat Prod Deri. 2010;24(1):49-53.

34. Alqahtani A, Hamid K, Kam A, Wong KH, Abdelhak Z, Razmovski-Naumovski V et al. The pentacyclic triterpenoids in herbal medicines and their pharmacological activities in diabetes and diabetic complications. Curr Med Chem. 2013;20(7):908-31

35. Rösen P Nawroth PP King G, Möller W Tritschler HJ Packer L. The role of oxidative stress in the onset and progression of diabetes and its complications: a summary of a Congress Series sponsored by UNESCO-MCBN, the American Diabetes Association and the German Diabetes Society. Diabetes Metab Res Rev. 2001:17(3):189-212

36. Badarinath AV, Rao KM, Chetty CM, Ramkanth S, Rajan TV, Gnanaprakash K. A review on in-vitro antioxidant methods: comparisions, correlations and considerations. Int J Pharm Tech Res. 2010;2(2):1276-85

37. Tan $Y$, Chang SK, Zhang Y. Comparison of $\alpha$-amylase, $\alpha$-glucosidase and lipase inhibitory activity of the phenolic substances in two black legumes of different genera. Food Chem. 2017;214:259-68
GRAPHICAL ABSTRACT

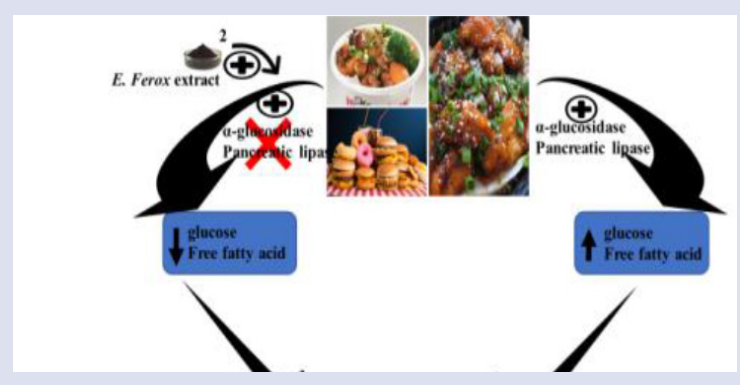

\section{SUMMARY}

- The study revealed that Encephalartos ferox leaves through inhibition of pancreatic lipase, $\alpha$-glucosidase, lowering intestinal glucose absorption and mopping of free radicals can prevent diabetes and its complication.

\section{ABOUT AUTHORS}

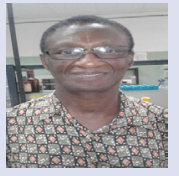

Prof. Andy Rowland Opoku1 obtained his $\mathrm{PhD}$ in 1977 from the university of Manchester, United Kingdom. He had academic positions in Various universities across Africa. Currently he is working as professor emeritus in the University of Zululand, South Africa with lots of publications.

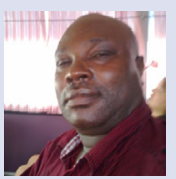

Prof. Godfrey Elijah Zaharare bagged his PhD in Agronomy/crop nutrition from the University of Queensland Australia in 1977. He is currently the head of Department of Agriculture in the University of Zululand, South Africa. $\mathrm{He}$ is a C3 level rated NRF researcher in South Africa. He is funded by EXARRO for rehabilitation of mined out land and receives funding for the domestication of Indigenous plants in Kwazulu Natal's Northern District. 

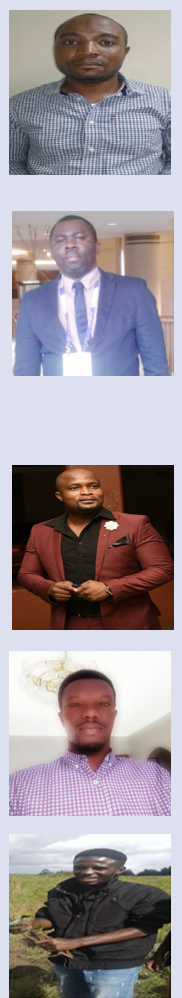

Dr. Rebamang Anthony Mosa obtained his PhD in Biochemistry in 2014 and is currently a serving as a Senior Lecturer and Researcher at the Department of Biochemistry and Microbiology, University of Zululand, South Africa. He has significantly contributed in the field of Medicinal Plants Research with a notable number of publications in peer-reviewed and accredited journals. He is also a member of South African Council for Natural Scientific Professions (SACNASP) as well as the South African Society of Biochemistry and Molecular Biology (SASBMB).

Dr Foluso Oluwagbemiga Osunsanmi is currently a Researcher at the Department of Agricultural Science, University of Zululand, South Africa. He is a biochemist with nineteen years work experiences both in academic and industrial sectors. He had notable publications in reputable journals and had presented both in local and international conferences. He regularly performs peer review for twenty-two different reputable journals. He is an Academic Editor of many International journals. He is also member of South Africa Association Council for Natural Scientific Professions, South Africa Association of Clinical Biochemistry, South Africa Association of Botanist and National Association of Safety professional.

Mr. Nkosinathi David Cele obtained his MSc in Biochemistry, from the University of Zululand, South Africa in 2017 and he is currently a 3rd year PhD candidate in the same University in the Department of Biochemistry and Microbiology.

Mr Michael Osawemi Oboh finished from Ambrose Ali University, Nigeria in the year 2010 with a BSc (honours) degree in human Physiology. In the year 2017, he obtained an honours degree in Biochemistry from the University of Zululand, South Africa. At present, he is a 2nd year Masters' student in the Department of Agriculture in the same University.

Mr Michael C Ojo bagged his BSc honours degree in Biochemistry in the year 2010 from the University of Benin, Nigeria. An honours award in Biochemistry was added to him in Biochemistry from the University of Zululand, South Africa in 2017. He is the first and corresponding author of the article.

Cite this article: Ojo MC, Osunsanmi FO, Zaharare GE, Mosa RA, Cele ND, Oboh MO, et al. In-vitro Anti-diabetic and Antioxidant Efficacy of Methanolic Extract of Encephalartos ferox leaves. Pharmacog J. 2019;11(3):455-60. 